\title{
THE BRITISH (KCLPATION OF ECYPT
}

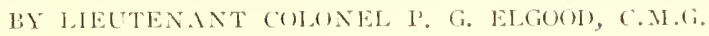

F IVE IILNDRlid) bars before the birth of Christ, Caubyses the P'ersian swept across sinai and planted his standard in Nenphis and Thebes. It was the end of the I'haraonic Empire, and from the calamity Egypt tid not wholly recorer. One invader has succeeded another and the tale is not yet complete. For twenty centuries and more, Egrpt has been the victim of confuest and satrapy.

The French cocupation (1798-1801) was a turning point in the history of Egypt. It gave a fresh lease of life to Turkish sovereignty, but it also producerl a man in Molnanmed Ali, who laid the foundation of Egypt's present prosperity. But his government was tco personal, too arbitrary to outlive his times: nor did it clo so, as subsequent history testifies. Of tbbas, a grandson, and Said, a son, little need be said, but Ismail, another grandson, who ascencled the throne in 1863, requires longer mention. About his memory so many stories revolve that the true is not easy to separate from the false. Iet this much is certain: during his short reign of sixteen years he brought Egypt to the brink of beggary. It his accession the public debt stoorl at $\mathcal{E}$ E. 3,000,000; at his abdication it anrounted to $\mathcal{E}$ E. $100,000,000$, and for the major part of that formidable total there was little to show. The country conld well afford to support its ruler's whins in the beginning. Nar was raging in the Lnited States and the spinners of Europe were paying fabulons sums for Egyptian cottcn. Then the golden harvest dried up, and Ismail Legan to borrcw at ruinous discounts or rates of interest. Two instances will suffice. ()ut of a nominal loan of $f \mathrm{E}$. 32,000,000 floated in 1873, Egypt received $f$ E. 11,000,000 in casl and $f$ E. 9,000,C00 in depreciated script, and for the accommodation paid in annual interest $\&$ E. 2,156,000. At another moment in return for a cash arlvance of $f \mathrm{E}$. 72,000 , the sovereign handed over f E. 230,000 of legyptian stocks. Finance of this type carries its own penalty, and in midsmmmer 1855 the borrowing came to an abrupt end. Alarmed at Ismail's personal extravagance, European bankers would lend no more. In despair he offered to a syndicate in Paris the 177,000 shares stuscribed by his predecessor to the Suez Camal Company: but doubtful of the value of the security, the syn- 


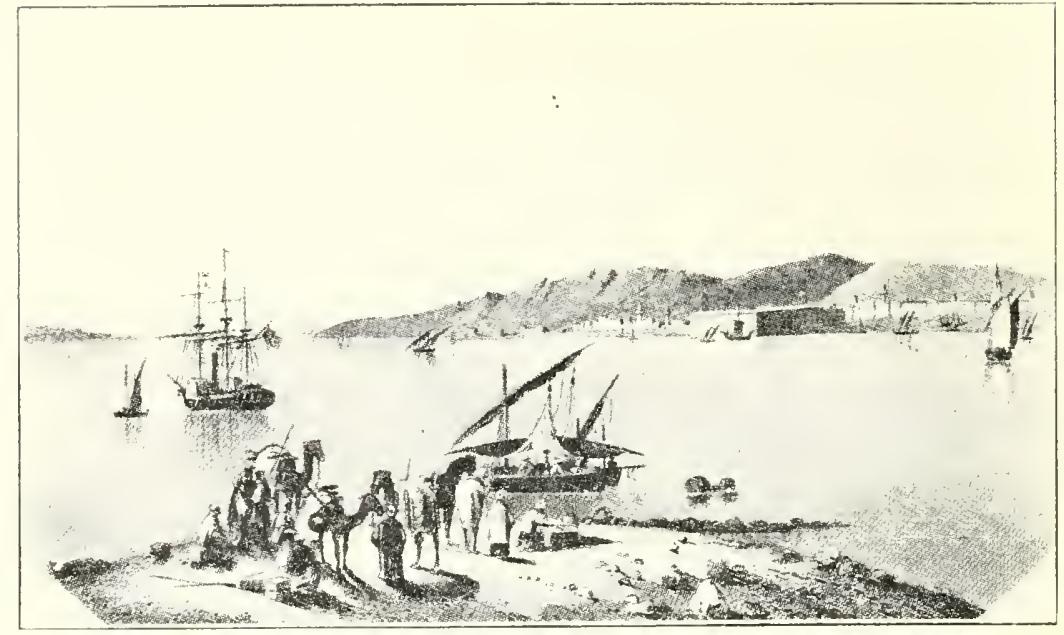

Courlesy of Longmans Green \& Co.

THE SEEZ ROATSTEAT MBOL"T 1840

From British Routes lo Indid. II. L. Hoskins

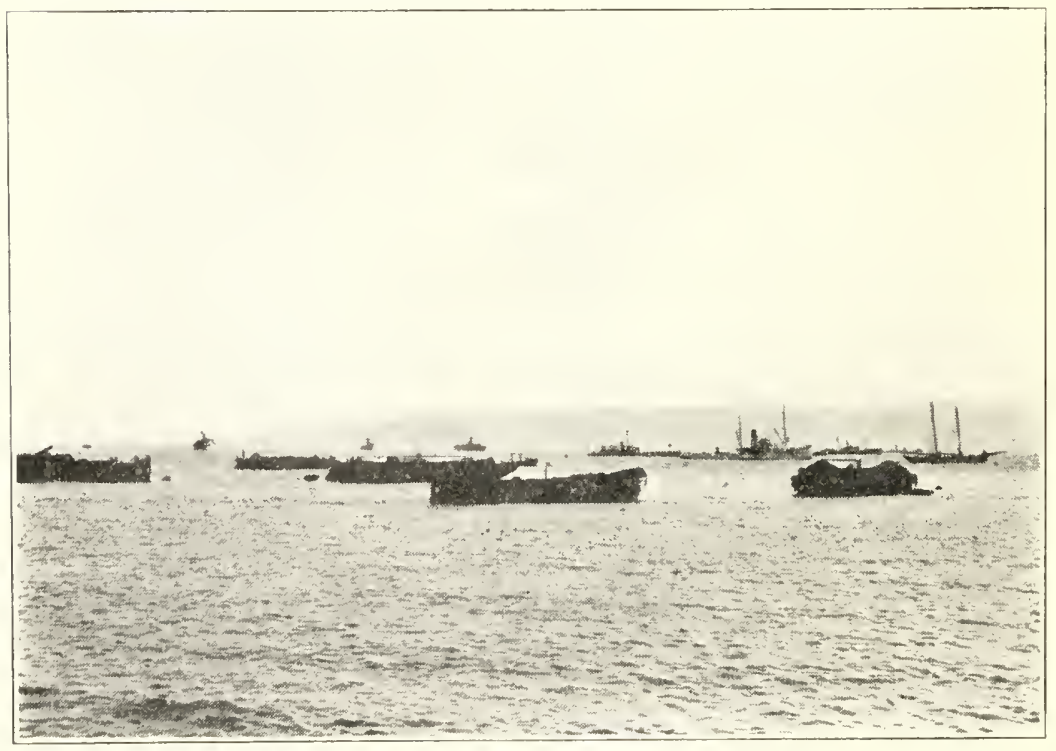

courtesy of H. L. Hoskins

THE SLEZ ROADSTEMD TODAY 
dicate hesitated, and getting wind of the negotiations, Disraeli nn behalf of England bonglut the shares for $\mathcal{E} \mathrm{E} .4,000,000$. Hitherto the domestic concerns of ligypt had been of no particular interest to England. If investors chose to speculate in Egyptian securities. it was their concern and not that of the (abinet. liut partnership in the Suez Canal altered this point of view: England no less than France thenceforth was directly interested in the maintenance of stable government in Egyjt. None the less. Disraeli had no intention of embarking upen any adventre in that conintry, and to Ismail's protests of solvency he turned a cleaf ear. The end came in June, 1879. when the Sultan of Turkey, pushed hy England and France, fereed him to abdicate. Ismail conld hardly complain of the fate that had orertaken him. His wilfulness and extravagance had well nigh ruined Egypt, ancl posterity will remember him more kindly for his creation of the Mixed Courts.

Tewfik, his son, succeeled. The new reign began inanspiciously with low Niles, poor harvests and epidenics which tonk toll of man and beast. Lnder the strain Egypt bent, and songht in vain for relief. It was not to be found. England and France, endeavoring to ward off bankruptey, had succeeded in promulgating a law of lifuidation (1880) that lightened part of Egypt's heary burden, hut taxation was still intolerably high and justice seldom obtainable. Tewfik, a simple-minded and frugal man, was no nuler to ricle the storm, and matters went from bad to wrse. In their plight the people turned to Islan for comfort, and al-Azhar, the seminary of lslamic lore, in return whispered of the need of brotherhocd of Moslems. Out of the wild talk of Alims and sheilihs, there sprang 11] a hatred of Europeans, and a belief that their interference in the affairs of Egypt was at the root of her ills. Under these influences a crudely national party came into existence, that planned to dethrone the sovereign and establish a reptblic. leed by Araloi, the army was the first to show its hand. Military grievances were numercus and legitmate enough, lut Tewfik did not handle the business well. He accepted a national nunistry, gave Iral)i the portfolio of war. It was a rash experiment, and the new minister took every advantage of his authority. There seemed no alternative Jut intervention, yet England in particular hung back. She had joined France in a llual control of Egyptian finance without enthusiasm, she harl held alonf from the commission of public debt, 
she had refused to nominate an Englishman to supervise collection of Egyptian revenue. She had never coveted possession of Egypt. she did not desire it now.

In the end many unoffending Europeans lost their lives in the tumultous days of Jume, 1882. The patience of the British admiral gave way: getting no answer to his letters of remonstrance, he opened fire on the forts of Alexandria July 11. France did not participate. Her conmitments in northern Africa were already heary, and she was reluctant to add to them. It was thus left to England to fulfill the Anglo-French promise to support the authority of the throne. Military operations succeeder naval: news of Arabi's intention to destroy the Suez Canal transferred the campaign from Alexandria to Isnailia. The British and Egyptian forces met at Tel el Kebir on the 10th of September in an engagement ending in the rout of the latter and the capitulation of Cairo. Thus began an cecupation, which continues to this day.

In a sense England had accomplished her mission. Order had been restored, trabi and his confederates were prisoners of war: there seemed no great reason to retain a garrison in Egypt. But decision was not $\mathrm{s}$ sinple as that: the future would remain doubtful. until the worst of Egypt's grievances had been redressed. They were legitimate and manifold, and an impartial survey of Egyptian conditions in the attumn of 1882 justified the impression that abuse of authority was at the bettom of the evil. The throne itself was the worst offender: its word was law, its prerogative was illimitable. It imposed burdens upon the people by simple decree, it drew no distinction letween national rerenue and the civil list. The incidence of taxation was painfully imperfect: the hearier burden fell uprn the wretched peasant. The kurbash and the prison were the twin pillars of the administration, and provincial anthority used both mercilessly. Crime also was rife; no man's life or property was safe in a country were brigandage and blackmail marched hand in hand. Various departments of the State neerled reconstruction: everywhere corruption and indolence reigned supreme. Irrigation was in deplorable straits. Incompetent engineers wasted the valuable summer water, neglected to keep in repair public works. The barrage, Mohammed Ali's great conception, at the apex of the Delta, stood unusable: its foundation had subsided, its piers were cracked. Military service was another affliction. Pay was generally in ar- 
rears, the term of engagoment illegally extended, the ration issue insufficient. Robbed and maltreated, conscripts deserted right and left. No less oppressive was the corric or sistem of forced labor. which swept the comntryside clear of able-bodied fellahin in order to construct works frequently of questionable utility and to cleat canals and drains for the henefit of wealthy landowners.

Hesitatingly the liritish cabinet reached four conclusions: first. that a peaceful Egypt depended upon the removal of grievances: secondly, that reconstruction of the administration alone conld renove the grievances: thirdly, that England would indicate the method of reconstruction; and lastly, that Pritish troops must remain in Egypt nutil the task was acconiplished. There had never been talk of ammexation or of prolonging occupation once stability was assured. Lord Dufferin as special High Commissioner came to Cairo to lay the foundations of constitutional government. His mis sion went $n 0$ further than a modest experiment in organic law he was to maintain the throne with a drastic restriction of its former prerogatives. No new tax in future was to be imposed withont consent of a General Assembly, no new measures could become law until a Legislative Council had debated it. It was Egypt's first introduction to representative government.

Meanwhile Europe was divided. Germany, Italy, and Austria saw nothing unreasonable in England's programme: France and Turkey hetly contested it. The indignation of France was natural. but illogical. Having refused to coöperate in the disagreeable business of intervention. she was not in a position to complain. She vented her annoyance in pressing England to specify the date of the army of ccenpation's departure: a curestion that the British Cabinet wonld only answer by the formula "as soon as the state of Egypt permits." But conscience was pricking Mr. Gladstone, the prime minister. He was anxious to remain on good terms with France, he was also desirous of relieving his conntry of the cost of maintaining the army of occupation. Spurred by this reasoning he decided to reduce the force in Egypt to the limit of a small garrison in Alexandria as the first step toward evacuation.

However, before a soldier conld move; orders were countermanded. The southern Sudan was ablaze with revolt. Isolated Egyptian garrisons, making what terms they conld, had capitulated: Khartoum, the capital, was in danger. Impressed by that menace. 
the Egyptian prime minister hastily conscripted 10,000 fellahin, and bacle their commander, General Hicks, stamp out the insurrection. But Hicks was trapped in the deserts of Kordofan, his travesty of an army wiped out. At once England pressed on Egypt the need of eracuating Khartoum while there was yet time: but neither the ruler nor his ministers would listen. "Let us talk of evacuation," said the prime minister testily, "when we've beaten these insolent rebels." It was a vain boast, for Egypt had neither the troops nor the money to molertake the reconquest of the Sudan, and England declined to lend either. In the end Egypt gave way, and General Gordon was selected to conduct the evacuation.

Throughout isst Lord Cromer, British agent and consul general, was patiently struggling with other embarrassments. Egypt was confronted with $\&$ E. $8,000,000$ of pressing liabilities with no money to give. Even the right to borrow had been denied. To meet emergencies and provide money for current needs. Cromer convincingly urged an immediate loan of $£$ E. 9,000,000. To demonstrate their complete disinterestedness in Egypt the British government inrited the coopperation of Europe, and the convention of London in 1885 gave Egypt a fresh start by placing $\&$ E. $9,000,000$ at her disposal. It this point England vaguely took stock of her responsibilities in Egypt. They were growing apace, and she contemplated transferring their burden to other shoulders. Turkey, the suzerain Power, was the obvious alternative and was invited to take up the task. The Sultan was very willing, and his representative, Muktar Pasha, met Drummond Itolff in Cairo. But the two commissioners could not agree. Nulktar was for reconquering the Sudan as a leginning. Wolff for reform and retrenchment in Egypt. The British cabinet then decided to negotiate directly with Constantinople. They offered to withdraw all troops within three years, reserving only right of reoccupaticn if circumstances required, and the Sultan would have signed an agreement on those lines but for the remonstrance of France and Russia. Mistakenly Turkey listened to the con'nsel, and her single opportunity of recovering control over Egypt passed.

Meanwhile Cromer was endeavoring to make one piastre do the work of two. The new loan provided $f$ E. 1,000,000 for (levelopment, and there was little doubt where the sum could be most profitably spent. Egyptian prosperity springs from intensive agriculture, 


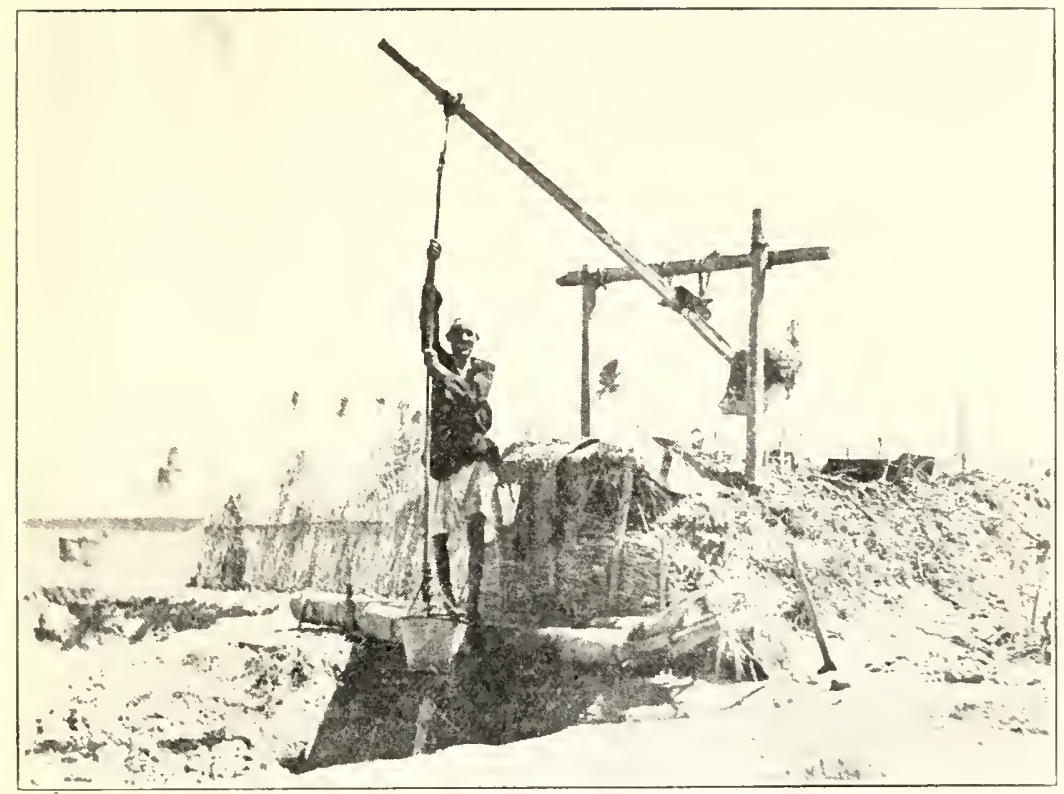

Courtesy of $\Gamma$. G. Elgoed

TIIE SII.II)( )

In ancient methos of irrigation still used.

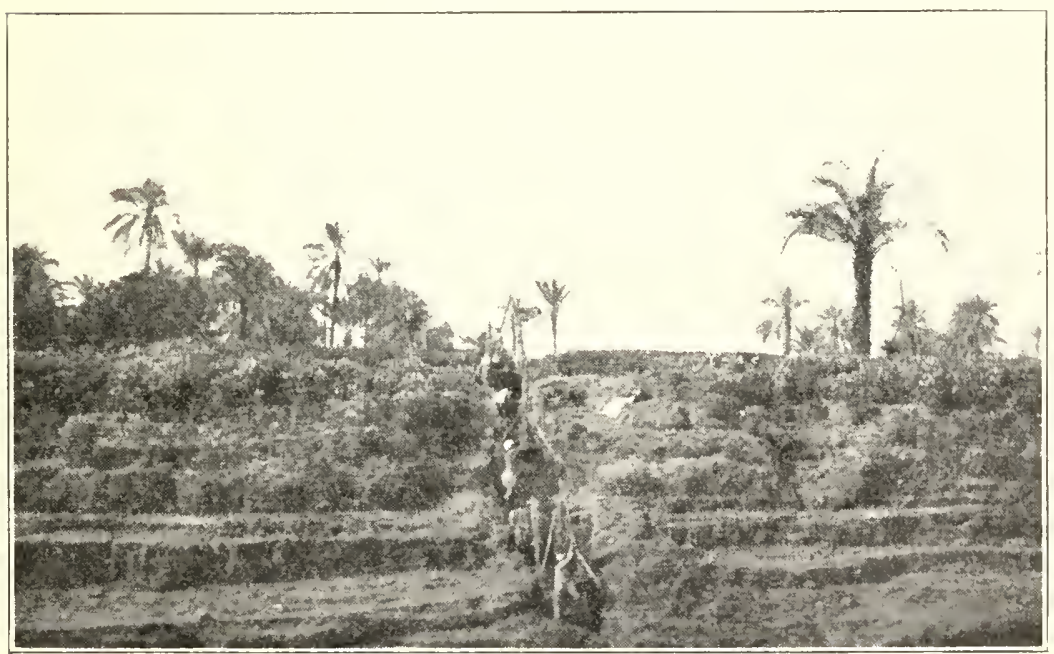

Courtesy of Dr. H. T: Neal

TIE TIME-IIONORET METIIOD OF IRRIGITION 
which in turn depends upon a punctual and aderuate supply of summer water. To assure that elementary need Molnammed Ali had built his barrage, and to its reconstruction a little troop of British engineers applied themselves. The distribution of water and clearing of canals had been handled from time immemorial, though never very efficiently, by the corréc. Now a fresh difficulty supervened. Relieved from his fear of the kurbush nnder the new administration, the fellah ignored the summons of authority and stayed at home. Cromer for once was puzzled. Despite despairing cries from the ministry, remonstrances from provincial authorities and appeals from the land-owning classes, he would not reintroduce the kurbash: from lack of money he could not substitute paid labor. However, by skimping and paring, Egypt contrived to find the money from her own resonrces, and in 1890 the corace was formally and finally abolished. The outlook was then brightening. Pankruptcy no longer stared Egypt in the face, the dead weight of the Sndan had been lifted. A reserve fund had been created, and money was available at last to recondition administrative services. But the ministries of justice and interior were painfully in need of reform, and it was only by pointed reminders that in a conflict of wills the English voice must trimmp that the judiciary was reformed.

Tewtil died (Jannary 7. 1892), and his son Abbas Ifilmi sat on the throne. A wayward youth impatient of counsel and restraint, flattered and importuned by a court of parasites, he picked a quarrel with England at once. To the sagacious Croner the incident pointed a moral. He had hegin his work in the expectaticn that the Egyptian people vinder guidance would accomplish their own salvation: the attitude of the throne and of its advisers causerl him reluctantly to put away that hope. Lnless the process of reconstruction was quickened, he was forced to admit that a century would be insufficient for the task, and fortified with that belief he altered his procedure. Hitherto executive anthority had been exercised by Egsptians, and ministers as they thought fit followed or rejected connsel tended by Englishmen. That was now changed. It the sicle of each minister sat a Pritish adviser. whose word was law: at the elbow of the provincial under or governor was a British inspector armed with litthe less authority. It was not ideal adninistration: it led in the end to the exclusion of Egyptians from the more important offices of their govermment. It hastened reconstruction, no (loubt, but it also left a distrust of England's intentions. 
None the less, under it Egypt prospered. The Sudan was reconpuered, the administration purged of its grosser defects, and of the many obstacles that had hindered regeneration. there remained only the jealousy of France and the burden of the capitulations. Fron the first days of the occupation France had hindered and thwarted liritish plans, less ont of affection for Egypt than from desire to pay off diplonatic scores elsewhere. But in 190 t the moment seemed opportune to comc to an understanding: then France needed liritish gocd-will in Moroce as much as England needed the good offices of France in Egypt. Thus came about an Anglo-French declaration, that left England a free hand in Egypt. The capitulations were less easy to landle. Lnder them the foreigner escaped arbitrary taxation and arrest, and treaty and tradition consecrated those elementary rights. But in the nineteenth century the burden had become embarrassing: hefore applying either taxation or laws to the foreign connmunity, Egypt had first to obtain consent of the fourteen capitulatory Powers. It seemed to Croner an archaic procedure, and he proposed to substitute for the l'owers a lceal conncil representative of resident foreigners.

The indignity of the proposal rankled: already wounded by a convention ( January 11, 1899), recognizing an Anglo-Egyptian condonininum in the Surlan, and by France's acknowledgement of the occupation, Egypt stirred measily. Out of the resentment was born a naticnal party led by Mustapha Kamil, an inspiring personality, whose fierce denunciation of the occupation found an echo in the hearts of his fellow-conntrymen. Abhas Hilmi patronized him. sheikhs and notables hung upon his words. All Egypt was convulsed with the struggle, but Cromer did not stay to see its conclusion. He had written his last despatch, had spoken his last word, and in the spring of 1907 he lajd down his stewardship. It had been a memorable one: it had rescued Egypt from insolvency, it had planted the seed of virtuous administration. No man had ever served her better.

England was now at the parting of the ways, mcertain whether Egypt would responcl best to further Anglicization of the government, or to a reversion to earlier idleals. Sir Eldon Gorst, taking Cromer's place, had no doubts: he indicated at once his intention to curtail the power of alvisers, to restore to ministers their old predominance in administration, to limit British infuence in the civil service. The policy worked admirably for a while: the throne coöperated enthusiastically and a new prime minister in full sympathy with 
Egyptian aspirations took office. The natimal party began to disintegrate. There was a short struggle for supremacy between it and the cabinet, but Mustapha Kamil was deatl, and his mantle had fallen upon less capalile men. Moslem and (opt fell out: rival congresses embittered the dispute.

(iorst dicl not live to enjoy the frutit of his labors: in 1)11 he went he me to die. (riticism and comment pursucel him to the grave. With one veice the foreign community condemned his policy ats premattre, and Europe agreed with the judgment. Nevertheless, he had ploughed too deep for a suecess r to disturb his work, ner did lord kitchener attentst to do so. That remarlable man was more concorned in the betterment of agrienltre than in the political aspiratit us of Egypt, and he flung himself into its stuly. There was, no (1)ulut, room for a vigorous hand. Cotton, the staple crop, was de-

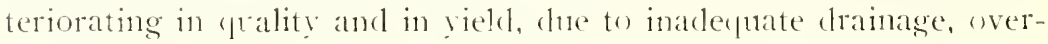
froduction, and insect pests. Meanwhile, pulation was increasing by leaps and bounds while the area of cultivable land remained stationary. Common sense bade Fgylt in these circumstances to prepare against a day when economic pressure wonld oblige the fellahin to break virgin ground, and Kitchener cast an inguiring eye upon the extensive lakes and marshes that horker the Mediterranean shore. Their reclamation was an extensive undertaling, and Kitchener wat perhaps in too great a hurry to seceech. lint if his execution wats at fault, his insight was true enough: Egypt can never have a sufficiency of cultivalle land. Meanwhile there hat arisen an insistent cry for parlianentary control of the executive, and reluctantly hitchener turned from agriculture to answer it. Corst's modest experiments in organic law had whetted Egyptian appetite for wider concessions and Kitchener thought to satisfy it by creating a single legislature, invested with larger attrilntions than the two chambers it displaced. He was mistaken: nothing short of parlianentary control Wulk nu: prlease Egypt.

IVar arrested the reflexion: nnexpectedly legyt fonnd herself a participant in the struggle. Turkey, the suzerain Power, entered the lists. intent on blocking the Suez Canal. Military authority in Egypt froclaimed martial law. The news shocked society. Martial law had a sinister note, a hint of actual hostilities by no means relieved by a later mderstanding that England "undertook the sole burden of the war without calling upon the Egrptian people for aid 
therein." It was a rash pronise: for no human intelligence conld predict in $191+$ the course and conseduences of the llorld War. Mrorse was to follow. l'eace lad sufficiently indicated the anomalies of a military occupation of Eygpt: war with Turkey walle their continuance impossible. I new form of government had to be derised. a new nationality provided for the Egrptian people. Innexation and antonomy were considered and rejected: the first was certain to promote suspicion anong neutral l'owers: the second, to increase diffentics in defending the suez (anal. lietween the two extrenes stood a protectorate: $1^{\prime}$ ) very satisfactory alternative in view of the earlier pledges given by England on the subject of the ocoupati: 11, but an expedient probably less open to objection than

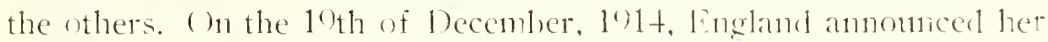
decision, and simultaneously invited l'rince llusein Kanel. som ot

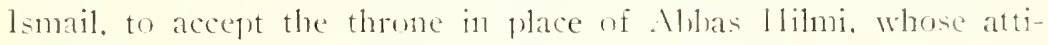
turde was suspect.

The Turkish attack on the canal failed dismally, but for the two years following Eggpt had to bear the ine nveniences incidental to a state of war. They were at first lisht enough, but in the sunnmer of 1917 that comfortable state of affairs cance to an end. Firitish strategy called for an invasion of Palestine. . Ycross Sinai grew 11p a long line of crmmunications, before fazal there lay a field arny needing labor and produce. For awhile Figypt provided both uncomplainingly: then the supply dwindled and military athority was foreed to requisition. Crops and animals were seized, labor was compulsorily recruited: a melancholy conment upon England's undertaking in 191t. None the less from the war Egypt profiter materially. Jler revente exceeded expenditure, her financial reserve increased. She had been saved from invasion. she har few dead to mouru. Igriculture had prospered. Her sarings probably amounted to $\&$ E. 150,000,C00: her exports and imports had cloubled in value. All this good fortme and more Egypt owed to her association with Fingland.

Meanwhile, President IVilson's inspiring reminder of the right of small nations to self-determination had stirred Egypt to the ruick. and following the armistice Sa'arl Pasha Zaghlul, a former Minister. stepped forward to champion his comntry's claim. He asked leave to discuss the grievances in London: for answer he was biciden to stay at home. It moved him to defiance. Te issued a stream of 
manifestoes, he called mpon Europe to mark the measure of England's iniquity. So violent grew his language that military authority sent Zaghlul to cool his tongue in Malta. His arrest was followed by wild disorder. Administration came to a standstill: a lust for blood and destruction fastened on the country. In some perplexity the Lritish prime minister commissioned Lord Allenby as a special High Commissioner first "to restore order," next "to maintain the King's protectorate on a sure and equitable basis." The first was easily accomplished. But Allenby's trimmph went no further: try as he would, he could not succeed in convincing Egypt of the virtue of a protectorate.

Such was the situation when Lord Minner, at the head of a commission of inquiry, arrived in Cairo. His welcome was ominous: he was bluntly recommended to confer with Sa'ad Zaghlul, then in Paris, or betake himself home. Moreover Milner was handicapped by his terms of reference: he was only empowered to discover a form of constitution that "under the protectorate" would satisfy Egrptian aspirations. No such formula could possibly be devised, and Nilner meditated upon a new line of approach. He met Zaghlul and a delegation, known later as the Wafd, in London, and boldly proposed a treaty of alliance between the two nations with acknowledgement of England's special interests in the valley of the Nile. He was prepared to be generous in turn-to withdraw the protectorate, to admit the sovereign independence of Egypt, to guarantee the conntry against aggression, to withdraw foreigners from the administration, to confine the duty of the British garriscn to the protection of the Suez Canal. It was not enough. Egypt coveted the Sudan also and Nilner regretfully broke off negotiations. Twelve months later Adli Pasha took u1p the thread. He was no more successful than Zaghlul, and Lord Curzon conld only believe that in commcn with the whole world Egypt was suffering "from the cult of disruptive and fanatical nationalism." Meanwhile Allenby in Cairo was by no means at his ease. Conciliation had failed. Negotiations had borne no better fruit and he conld think of no alternative but to offer Egypt her independence. Thus came about the unilateral declaration of the 28th of February, 1922, terminating the protectorate but reserving at the discretion of England security of imperial communications, defence of the Suez Canal, protection of minorities and foreign interests, and the future of the Sudan. 
Some months later came the promulgation of a constitution and the meeting of Egypt's first parliament with Zaghlul as prime minister. Through the first session lebate seldom wandered far from the reserved points, and Zaghlul went to Londen to settle them nn his own ternus. He retnined empty-handed, boasting of his failure, speaking of England as the irreconcilable enemy. His intemperate words threw the conntry into a ferment, his attitude towards the throne encouraged the cry of "revolution or Zaghlul." MLutiny among Egrptian troops stationed in the Surlan broke out, Sir Lee Stack, governor general of the province, was assassinated in the streets of Cairo. It was a scry business: the culminating crime of a long tale of political murders. Punishment followed: Zaghlul hicl his face in retirement, the constitution was suspended and parliament was dissolved. It was well for Egypt to have a respite from democratic govermment, and the new prime minister, Ziwar I'asha, wated six months for the conntry to recover its senses. Once more the elections went in faror of the IVafl, as Zaghlul's party was now universally called, and Ziwar hardly knew what to do. England with some reason was suspicious of a ITafdist ministry. Egypt would be exposed to further mortification, if Zaghlul came back to power. It was a dilemma from which Ziwar escaped by persuading the King to dissolve the new parliament.

But palace rule, however benevolent in intention, is never a satisfactory substitute for constitutional government, and it fell to Lord Lloyd, replacing. Allenby in the spring of 1925 , gently to remind the King of that truth. It must be said of the tumultous years which followed the declaration of independence, that His Majesty. Fuad the First, who succeeded to the throne in 191\%, had behaved with gcod sense and dignity. His position was always delicate and frequently extremely embarrassing. He had given parliamentary government a trial and found it wanting: driven to the opposite course, he found himself hedged about with constitutional limitations ill suited to a country so hackward as Egypt. Nor had it always been easy to reconcile his concern for the true welfare of Egypt with his duty towards her elected representatives. The two interests frequently conflicted, and decision was often perplexing. On this cccasion the elimination of Zaghlul made the way easier, and a new parliament met a new leader. It was a business-like assembly: party was forgotten in the interest of the State. Debate pro- 


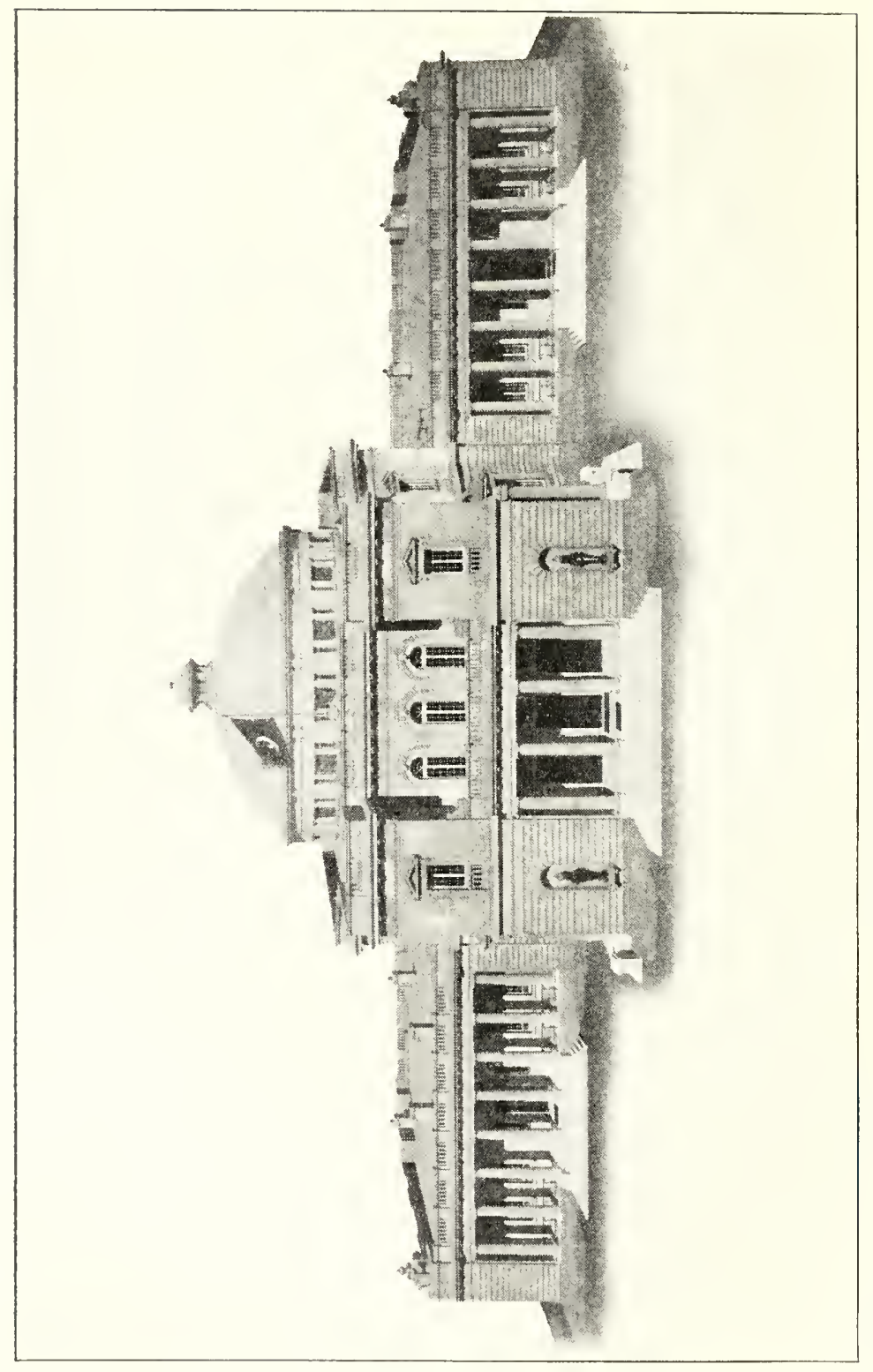

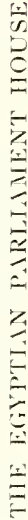

3
8
0
5
5
0
3
3 
ceeded smoothly, significant testimony that deputies recognized parliamentary govermment was still on trial.

Taking advantage of an official visit to 1,ondon, Sarwat, the new prime minister, called on Sir Ansten Chamberlain, minister for foreign affairs. He found that Englishman ready to discuss a settlement of the reserved points, and out of the conversation energed another draft treaty, making stustantial concession to Egyptian sentiment. It might have encled the differences lout for an obstinate belief on the part of a parliament wholly Irafdist, that this party alone must have the honor of negotiating a settlenent. Sarwat was not a member of it: his relations with Mustapha Nahas, the successor of Zaghlul now dead, were by no means cordial. Presently the whisper passed that Egypt was betrayed, and fearful of forcing an issue. Sarwat resigned. Nahas stepped into Sarwat's shoes, and at once picked a quarrel with England. Te paid dearly for the temerity. Chamberlain took advantage of the dispute to remind Egypt that she must not interpret the four points reserved under the Declaration of 1922 as she thought fit, and Nahas, accepting the inplication, made way for Mohammed Pasha Mahmoud. Some change was necessary in the interests of Egypt. To many Egyptians anxious for a settlement with England, the pretensions of the Mafd had become intolerable. Rehind that party stood no doubt the bulli of the electorate, but a parliamentary majority, however important in domestic issues, is less so in negotiation. In that field negotiators must have not only a sense of statesmanship but some accuaintance with the virtue of compromise, and there was no sign that Nahas or his colleagues enjoyed either. Marking the moral, Mohammed Mahmoud prevailed on the King to suspend parliament. Ilis term of office was too short to accomplish much, but he succeeded at least in persuading England to acknowledge Egypt's paramount right over the waters of the Bhue and IThite Niles. That achievement. in itself of no small merit, passed unnoticed in the news that Nohammed Mahmoud had wrung out of Mr. Henderson, a new foreign minister, a treaty more favorable to Egypt than his predecessors. There was the customary stipulation that Egypt must approve the draft, and Mohammed Nahmoud returned to Cairo to prepare the electoral rolls. It was not his good fortune to carry negotiations 
with England to the end. The elections ended in an overwhelning victory for Ninstapha Nahas, and once more prime minister, that Egyptian went confidently to Jondon. I le was no more successful than his predecessors, Sat Zaghlul and Xdli, had heen nine years earlier. The Surlan was the stmmbling block. Egypt would not abate her claim to sovereignty, England could not afford to satisfy it.

Recalling the snspension that had lefallen earlier parliaments, Nahas set to work to gnarantee his own against a similar misfortune. Lnder his anspices suspension or even modificaticn of the Written constitution of 1923 becane an act of high treason, and punishable by a new supreme court of justice. Tt was ton much for the gord sense of the King" to arlmit, and with excellent discretion he refused his assent to the bills. The Mafd rushed on its doom: it swore to defend the constitution at all costs. In this wise the issue narrowed to a contest between the throne and the party. The first picked up the challenge. Ismail Pasha Sillii formed a new cabinet of ministers unidentified with any particular party, and the King adjourned parliament indefinitely.

In vain the Wafd protested, in vain it called on Egypt to pay no taxes: Sidki answered the defiance by proscribing all public meetings of the ITafd, confiscating its manifestoes, suspending newspapers that dared to publish them. There were whispers of revolntion, but Sidki had the armed forces of the crown at his back. Presently he was ahle to publish a new constitution withont provoling fresh disorder. To many Egyptians Sidki's constitution was the negation of democratic govermment, the trimmp of the throne at the expense of the people. Among their number was the late prime minister Mohammed Mahmond, who advised the electorate to boycott the conning elections. To that daring connsel Sidli answered smoothly: he begged his adversary to reconsider the decision, he guaranteed no interference with the polls, he spolie of the need of a united nation to reppen negotiations with England. Tut his nndertaking went no further than words. He banned a national congress called by the Wafd. he ignored a declaration signed by fonr ex-prime ministers and twenty three ex-ministers that not only contesterl the validity of elections under the new crnstitution, but warned England that no treaty negotiated by Sidki would bind Egypt. Yet despite that protest, few observers conversant with Iigypt could doubt how the poll would go. Sixty-five per cent of the 


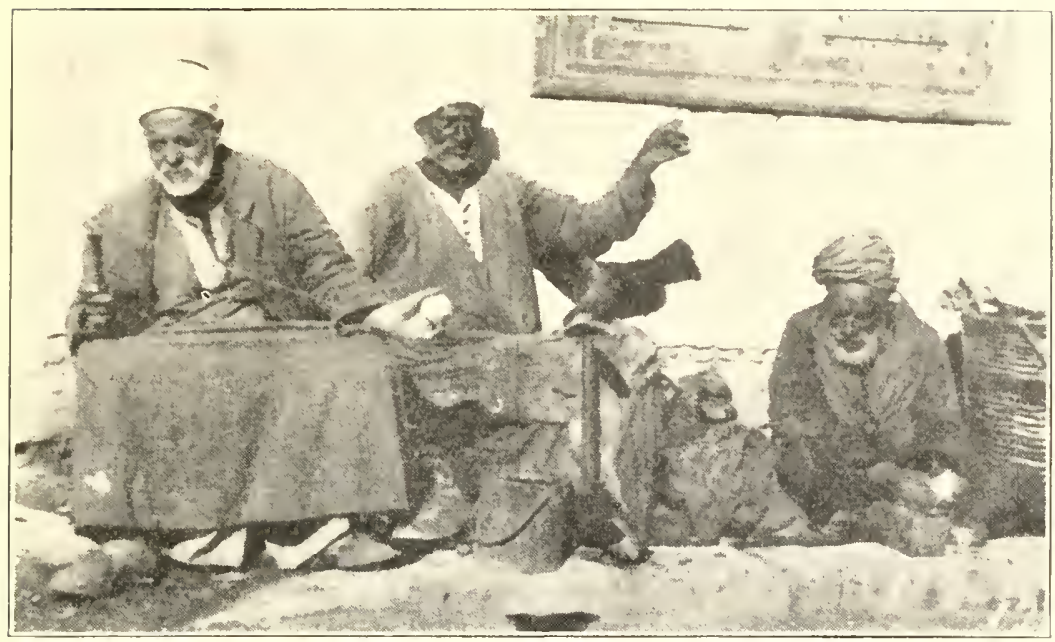

Courtesy of P. G. Elgood

VILLAGE ARTISANS Voters of today

electorate were reported to have voted, and the result was a personal triumph for Sidki. None the less, considering that within the last eight years four parliaments have sat, ten prime ministers have held office, it would be rash to assume that the life of the present parliament or of the present calinet will be long.

Such briefly is the story of England in Egypt: a stewardship in effect of which England has no need to be ashamed. She has nursed her charge to adolescence. she has provided it with ideals of citizenship: so much at least will be admitted by posterity. The political history of the occupation may be conveniently divided into five phases. Indecision distinguisherl the first: England could not hit upen a consistent policy, much less name a date when the occupation would end. That uncertainty died away, and a vague convicton that the interests of England and Egypt were permanently indivisible replaced it. War introduced the third phase: the proclamation of a protectorate followed. The fourth terminated in admission of Egyptian sovereignty, and the fifth still awaits conchsion. The Sudan remains the only obstacle now to settlement. If occupation constitutes a title to sovereignty, then it must be admitter that the Egyptian claim in law to the Sulan is substantial. With the confuest of Sennaar in 1820 by Mlohammed Ali and the annexation 
of the upper basin of the White Nile by Ismail fifty years later, the Suclan passed to the keeping of Egypt. But the administration of this vast dependency proved too difficult to he successful. Misgovernment and rebellion were a commonplace, and in 1886 Egyptian arms were forced back to IVadi Ilalfa. lint that retirement dicl not invalidate sovereignty, nor was the Egyptian title questioned until the reoceupation of the Sudan in 1898. Then England, who had partially financed the campaign and lent troops for the reconquest, claimed a predominant voice in the administration of the dependency. Her concern was with the Sulanese people; their welfare she believed should take precerlence of the interests of Egypt. There have been sethacks to that ideal and doubtful adventures: but England can at least claim that her administration of the Sudan has profited its inhabitants no less than herself. The foundations of selfgovermment have been laid, their development is assured: but until the process is completed England cannot with propricty withdraw from her task. So far 110 responsible Egyptians have yet indicated their intentions towards the Sudan: beyond postulating the sovereignty of Egspt over the whole valley of the Nile, they do not go. It is not enough: it is indeed debatable whether the people of the Surlan would acknowledge Egyptian rule.

Little has been said in the conrse of negotiation of the capitulations, and the ultimate disappearance of consular conrts adjuclicating between their nationals has been taken for granted. But the subject cannot be dismissed guite so cavalierly. Consular courts are not the only sinners, or the only jurisdiction that is inciependent of Egyptian sovereignty. To them must be added a dozen or more tribunals which adjuclicate according to their own tradition of practice on marriage, divorce, and inheritance. These tribunals are Egyptian, but the law they administer is personal to the community they represent. It would be well if Exypt repaired her own legal anarcly before crying for the abolition of consular courts. And perhaps the clamor would be less insistent but for a belief that with the consular conrts would go the capitulations. Certainly so long as capitulations exist, the sovereignty of Egypt is incomplete: more fallacious is the common belief that the European escapes taxation from their protection. It is not so, nor indeed would the foreign community olject in principle to taxes on income or even to death duties, provided the State will not discriminate against for- 
eigners. Luhappily on that point it feels little confidence, A supreme julicature international in type and embracing all existing tribunals and procedures, might conceivably furnish the guarantees the foreign community reguires: but twice in the past Egypt has rejected that alternative, and there is no reason to believe that she would not do so a third time.

Although taxation is inelastic and amending legislation is still cumbersone, Egypt's financial situation is one that many countries burdened with legacies of the war may well envy. Her public debt stands at the modest figure of $£$ E. 91,000,000, and the reserve fund swollen with budget surpluses of prosperous years equals two fifths of that sum. Lnhappily its investment is less satisfactory. Cotton is one offender. Confronted by falling prices the State bought half the 1928-1929 crop, and so locked up $\&$ E. 15,000,000 of the reserve. It was a rash adventure. The cultivator obtained no permanent relief, the State became entangled in a doubtful cperation. The market has not recovered, and a third of the cotton stored in the government go-downs still awaits a purchaser. The balance of the reserve is also heavily mortgaged. The beightening of the Aswan dam to hold up five milliard cubic meters of water in place of two and a half, the projected construction of a second reservor on the White vile forty miles south of Khartom, and of stubsidiary barrages, canals, and drains to distribute increased supplies of water, will exhaust the liquid reserve. And behind expenditure on irrigation are other commitments unrealizable and only indirectly remunerative: notably advances to cultivators, loans to coöperative and industrial societies, generous pledges of support to new agricultural and mortgage banks. Fet ligypt need feel no reason to be uneasy. Last year's accounts diselose a handsone excess of revenue over expenditure and the estimates for the forthcoming twelve months include a contribution of $f \mathrm{E}$. $5.000,000$ on accomnt of capital expenditure. I'rudent finance should show no less happy results in the future. The industry of the Egyptian cultivator, his courage in facing falling prices, the stability of the climate and the fertility of the soil are sufficient guarantees. None the less there are lean years abead, and Egypt would be well advised to consider her administrative expenditure. Econcmies have been made, no doult, but there is still ample room for further and more drastic cuts.

Within the past twelve years on five separate occasions Eng- 
land has endeavored to settle her differences with Egypt, and has failed. It is true that a government more stable in appearance than its predecessors holds office today in Egypt: but the country, nevertheless, is torn with faction and dispute, and until political parties lay aside their rivalries and approach England as a mited nation, it may be wiser to wait on time. Yet if the future is uncertain, at least England can look back on the past with humble satisfaction. Her achierement in Egypt cannot be und ne. The superstructure she has been at pains to build, may shake from time to time, but the foundations will not move. They are laid too well. 